\title{
Effect of Spearmint Leaf Extract on Crown Rump Length of Pups of Swiss Albino Mice
}

${ }^{1}$ Asma Zulfiqar, ${ }^{2}$ Muhammad Suhail, ${ }^{2}$ Javaid Iqbal, ${ }^{2}$ Tayyaba Muzaffar, ${ }^{3}$ Sitwat Mudassir

${ }^{1}$ Department of Anatomy, Fatima Memorial College of Medicine and Dentistry, Lahore

${ }^{2}$ Department of Anatomy, Shaikh Zayed Medical Complex Lahore

${ }^{3}$ Department of Anatomy, UCMD, University of Lahore

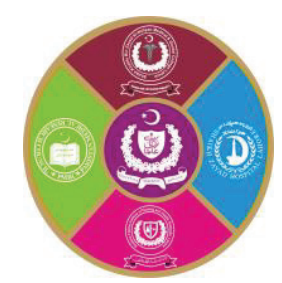

\begin{abstract}
Introduction: Spearmint (Mentha spicata L), a member of Labiatae family, is used as herbal medicine for treatment of different gastrointestinal and urogenital diseases. Aims \& Objectives: To evaluate the effect of spearmint leaf extract on crown rump length (CRL) of Swiss albino mice pups. Place and duration of study: This experimental study was conducted for 30 days in the Department of Anatomy, Shaikh Zayed Postgraduate Medical Institute, Lahore. Material \& Methods: 21 female and 7 male mice were used for this study. Pregnant female mice were divided into three groups each having 7 animals. They were labelled as group A (control), group B (low dose experimental) and group C (high dose experimental). Group A received distilled water while group B and C received $3 \& 6 \mathrm{~g} / \mathrm{kg} /$ day spearmint leaf extract respectively. On completion of gestation all the pups were delivered by hysterotomy. 28 pups from each group were selected randomly and labeled as A1 (control), B1 (low dose) and C1 (high dose experimental). Their CRL was measured and recorded. Results: CRL of pups in both experimental groups was decreased significantly with $\mathrm{p}$-value $<0.001$. The difference among the experimental groups was also highly significant statistically with $\mathrm{p}$ value $<0.001$. Conclusion: The present study reveals that spearmint leaf extract has a decremental dose dependent effect on CRL of Swiss albino mice pups.
\end{abstract}

Key words: Mentha Spicata Labiatae, herbal medicine, swiss albino mice, gestation, CRL.

\section{INTRODUCTION}

Spearmint (Mentha Spicata L) belongs to genus Mentha $^{1}$ and family Labiatae., ${ }^{2,3}$ Genus Mentha includes 25-30 species, some of them are spearmint, peppermint, curled mint, etc. Spearmint is the commonest mint having pungent taste. ${ }^{5,10}$ It is cultivated throughout the world ${ }^{5}$ but United States is its major producer. ${ }^{6}$ Small plant of spearmint has blue flowers that grow at the edges of the branches as narrow and long spikes. ${ }^{7}$ Common constituents of this plant are limonene, carvone, 1, 8-cireole and volatile oils among which carvone is present in large amount. ${ }^{8}$ LD50 of spearmint extract is $13,606 \mathrm{mg} / \mathrm{kg}$ in adult Swiss albino mice. ${ }^{9}$

Different parts of spearmint plant are used as home remedy for certain diseases of gastrointestinal tract, starting from the oral cavity, it is used for treatment of dental carries, anorexia, ${ }^{10}$ nausea, vomiting, ${ }^{11}$ hiccup, ${ }^{5}$ flatulence, ${ }^{5}$ bloody diarrhea ${ }^{12}$ and hemorrhoids. ${ }^{13}$ It reduces the chemotherapy induced nausea and vomiting when used along with the other antiemetic drugs. ${ }^{14}$ It is also helpful in treating some disorders of urogenital system for example in treatment of amenorrhea, dysmenorrhea ${ }^{10}$ and oliguria. ${ }^{13}$

Spearmint caused heartburn in humans (healthy volunteers) due to direct mucosal irritation without increasing the acid reflux or decreasing the pressure of lower esophageal sphincter ${ }^{15}$ and also produced dose dependent hepatic damage in male Wistar albino rats. ${ }^{8}$ In a human study spearmint had reduced the recurrence of nausea and vomiting induced by chemotherapy when given along with other antiemetic drugs. ${ }^{14}$

Histological sections of kidney tissues showed hydropic degeneration of epithelial cells, dilatation of tubules, enlargement of Bowman's capsule with focal infiltration of white blood cell in interstitial areas. Dose dependent atrophy of some tubules and glomeruli was also observed. ${ }^{16}$

As spearmint is used very commonly in nausea of pregnancy, the present study was designed to evaluate the effect of spearmint leaf extract on CRL of swiss albino mice pups. 


\section{MATERIAL AND METHODS}

This experimental study was conducted in the Department of Anatomy, Shaikh Zayed Postgraduate Medical Institute, Lahore.

Male and female mice were kept separately and acclimatized for 15 days. A twelve hours light and dark cycle was maintained at room temperature of $24 \pm 2{ }^{\circ} \mathrm{C} .{ }^{8}$ The food and water were provided to these mice ad libitum.

After acclimatization, one male and three female mice were kept together in a cage for a week for conception. Pregnancy was confirmed by presence of vaginal plug.

After conception female mice were randomly divided into three groups, A (control), B (experimental low dose) and $\mathrm{C}$ (experimental high dose), each having 7 female mice and were marked for identification with permanent markers of different colors.

Spearmint leaf extract was prepared from PCSIR laboratory, Lahore. Quantification of extract was done through Gas Chromatography-Mass Spectrometry (GC-MS) from Chemistry Department of Forman Christian College, Lahore.

Spearmint extract was given to the pregnant mice through gastric intubation.

GROUP A: Animals were given distilled water 15 $\mathrm{ml} / 100$ gm body weight per day for 15 days.

GROUP B: This was low dose experimental group, mice were given $20 \mathrm{~g} / \mathrm{L}(3 \mathrm{~g} / \mathrm{kg}$ body weight) of spearmint leaf extract for 15 days.

GROUP C: This was high dose experimental group, mice were given $40 \mathrm{~g} / \mathrm{L}$ ( $6 \mathrm{~g} / \mathrm{kg}$ body weight) of spearmint leaf extract. Duration of dosage was 15 days.

After euthanesia ${ }^{17,18}$ all fetuses were delivered through hysterotomy. 28 pups from each group were labeled accordingly as A1, B1 and C1. They were examined for congenital anomalies and their CRL i.e. length of the dorsal surface of the body of mice pups from external occipital crest to the center of anal opening ${ }^{19}$ was measured and recorded (Fig-1).

\section{Statistical analysis:}

The data was analyzed by using SPSS 20.0. Normality of data was tested by Shapiro Wilks Test. Mean, standard deviation, median and interquartile range were used as descriptive measures of crownrump length of pups (a quantitative parameter). As assumption of homogeneity of variance wasn't met, Kruskal Wallis ANOVA was applied for comparison of variable in groups and Mann Whitney $\mathrm{U}$ test was applied for post hoc analysis. Pvalue $\leq 0.05$ was considered as statistically significant.

\section{RESULTS}

The normality of CRL of pups of all groups revealed skewed distribution when tested by Shapiro Wilks test with p-value $<0.001$ (highly significant, Table-1) and homogeneity of variance was heterogeneous with p-value 0.016 (Table-2). The mean CRL of group A1 was $2.84 \pm 0.14 \mathrm{~cm}$, where as in groups $\mathrm{B} 1$ and $\mathrm{C} 1$ it was $2.58 \pm 0.10 \mathrm{~cm}$ and $2.38 \pm 0.12 \mathrm{~cm}$ respectively (Table- 3 ).

The mean and median of CRL were highest for group A1 and lowest for $\mathrm{C} 1$. The difference was found highly significant among three groups with $\mathrm{p}$ value $<0.001$ (Table-4, Fig-2), when pair wise comparison was made, the difference between control group and both experimental groups was highly significant with $\mathrm{p}$-value $<0.001$. There was highly significant difference between $\mathrm{B} 1$ and $\mathrm{C} 1$ with p-value $<0.001$ (Table-5).

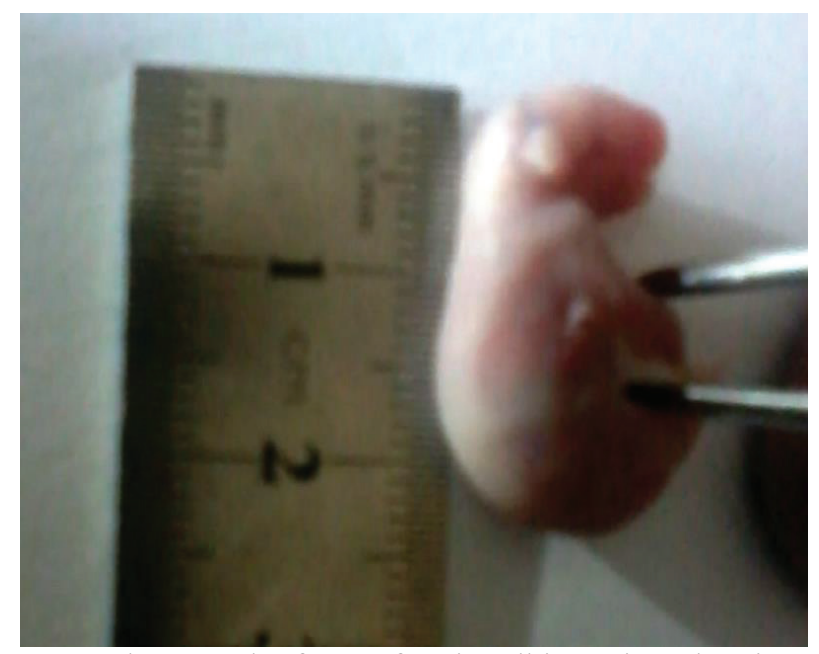

Fig-1: Photograph of pup of Swiss albino mice, showing its CRL measurement.

\begin{tabular}{|c|c|c|c|c|}
\hline \multirow{4}{*}{$\begin{array}{c}\text { CRL of } \\
\text { pups (cm) }\end{array}$} & Group & \multicolumn{3}{|c|}{ Shapiro-Wilks } \\
\cline { 2 - 5 } & Group A1 & .815 & 28 & $<.001^{* *}$ \\
\cline { 2 - 5 } & Group B1 & .850 & 28 & $<.001^{* *}$ \\
\cline { 2 - 5 } & Group C1 & .851 & 28 & $<.001^{* *}$ \\
\hline
\end{tabular}

Table-1: Test of Normality for CRL of Pups in Control and Experimental Groups

\begin{tabular}{|c|c|c|c|c|}
\hline & $\begin{array}{c}\text { Levene } \\
\text { Statistic }\end{array}$ & df1 & df2 & Sig. \\
\hline $\begin{array}{c}\text { CRL of } \\
\text { pups (cm) }\end{array}$ & 4.380 & 2 & 81 & $.016^{*}$ \\
\hline
\end{tabular}

Table-2: Test of Homogeneity of Variance for CRL of Pups in Control and Experimental Groups 


\begin{tabular}{|c|c|c|c|c|c|}
\hline \multirow{2}{*}{ Groups } & \multicolumn{5}{|c|}{ Crown-rump length of pups (cm) } \\
\cline { 2 - 6 } & Mean & SD & Median & Q1 & Q3 \\
\hline Group A1 & 2.84 & \pm .14 & 2.80 & 2.70 & 3.00 \\
\hline Group B1 & 2.58 & \pm .10 & 2.60 & 2.50 & 2.70 \\
\hline Group C1 & 2.38 & \pm .12 & 2.40 & 2.30 & 2.50 \\
\hline
\end{tabular}

Table-3: CRL of Pups in Control and Experimental Groups, at the Time of Dissection

\begin{tabular}{|c|c|c|c|c|c|}
\hline \multirow{2}{*}{ Group } & \multirow{2}{*}{$\mathbf{N}$} & $\begin{array}{c}\text { Mean } \\
\text { Rank }\end{array}$ & \multicolumn{2}{|c|}{ Kruskal Wallis ANOVA } \\
\cline { 3 - 6 } & & $\begin{array}{c}\text { Chi- } \\
\text { square }\end{array}$ & df & P-value \\
\hline Group A1 & 28 & 68.32 & 63.9 & 2 & $<0.001 * *$ \\
\hline Group B1 & 28 & 42.29 & & & \\
\hline Group C1 & 28 & 16.89 & & & \\
\hline Total & 84 & & & & \\
\hline
\end{tabular}

Table-4: Comparison of CRL of Pups in Control and Experimental Groups (by using Kruskal Wallis ANOVA)

\begin{tabular}{|c|c|c|c|c|}
\hline $\begin{array}{c}\text { (I) } \\
\text { Group }\end{array}$ & (J) Group & $\begin{array}{c}\text { Mann } \\
\text { Whitney U }\end{array}$ & Z-Approx & P-value \\
\hline $\begin{array}{c}\text { Group } \\
\text { A1 }\end{array}$ & Group B1 & 61.0 & -5.56 & $<0.001^{* *}$ \\
\cline { 2 - 5 } & Group C1 & 0.0 & -6.50 & $<0.001^{* *}$ \\
\hline $\begin{array}{c}\text { Group } \\
\text { B1 }\end{array}$ & Group C1 & 67.0 & -5.47 & $<0.001^{* *}$ \\
\hline
\end{tabular}

Table-5: Pair Wise Comparison of CRL of Pups in Control and Experimental Groups (By Using Mann Whitney U Test)

Key

df degree of freedom

F f-test (Ratio of variances)

Sig. $\quad$ significance (P-value)

$* * \quad$ highly significant difference $(\mathrm{p}$-value $<0.001)$

* $\quad$ significant difference $(p$-value $<0.05$ )

SD standard deviation

Q1 middle of first half of data

Q2 median

Q3 middle of second half of data

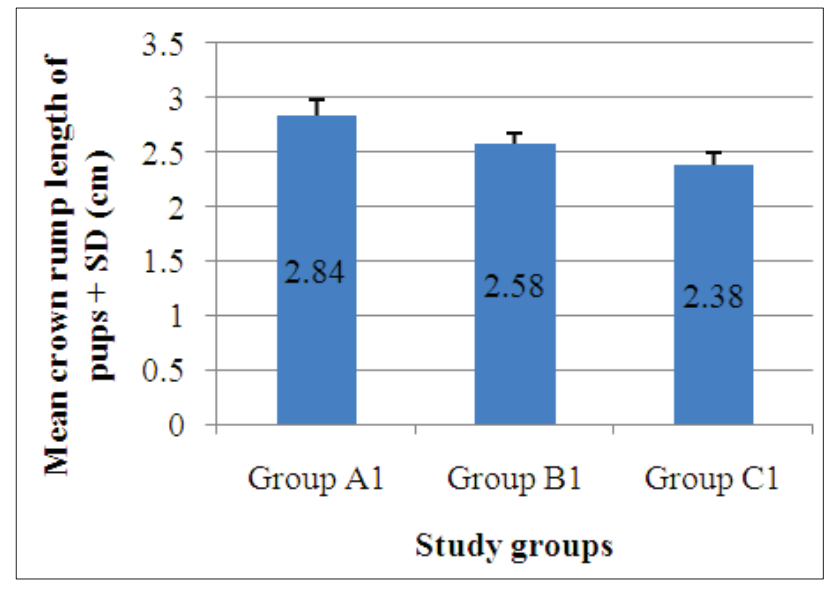

Fig-2: Graphic comparison of CRL (cm) of pups of control group and the experimental groups, exposed to spearmint leaf extract.

\section{DISCUSSION}

Spearmint is a common constituent of East Asian and Indian diet. ${ }^{20}$ It is used in medicines, candies and chewing gums etc. ${ }^{20,26}$ It is used as herbal medicine for certain diseases of GIT $^{25}$ and urogenital system. ${ }^{11,13}$ Spearmint increases the activity of cytochrome $\mathrm{P} 450^{21}$ and decreases the blood concentration of some hormones. ${ }^{20,22}$

In the current study CRL of pup was recorded and found decreased in both experimental groups. The mean CRL was lowest for group $\mathrm{C} 1$ and low in group B1 when compared with group A1. This difference was highly significant statistically with $\mathrm{p}$ value $<0.001$ (table-4), the difference between B1 and $\mathrm{C} 1$ was also highly significant with $\mathrm{p}$-value $<0.001$ (table 5). This showed that the result was dose dependent.

Similar findings were observed by Malinezaman et al in 2014 that showed the CRL of all pups of rats was significantly decreased in both low dose and high dose experimental groups, where adult pregnant rats received dill/soya seeds extract for 10 days i.e. for two consecutive estrous cycles, whereas untreated male rats were used for mating in this study (the active ingredient of soya is also carvone). ${ }^{23}$ The effect of soya on growth of fetus may be attributed to its effects on molecular and cellular levels. ${ }^{24}$

CRL of pups was unchanged when measured in pups of spearmint treated male rats where spearmint was given in doses of $10,20 \& 40 \mathrm{mg} / \mathrm{kg}$ per day for 45 days and after administration of last dose these rats were cohabitated with female rats (untreated) for mating. ${ }^{25,26}$ 


\section{CONCLUSION}

The results of present study showed that spearmint leaf extract caused reduction in CRL of pups of Swiss albino mice when given in low and high doses. Hence it is recommended that the use of spearmint leaf and its products should be minimized during pregnancy in humans as well to avoid such complications.

\section{REFERENCES}

1. Kizil S, Hashimi N, Tolan V, Kilinc E, Yuksel U. Mineral content, essential oil components and biological activity of two Mentha species (M. Piperita L., M. Spicata L.). Turk J Field Crops. 2010; 15:148-53.

2. Mandana B, Russly AR, Ali G, Farah ST. Antioxidant activity of spearmint (Mentha spicata L.) leaves extracts by Supercritical Carbon Dioxide $\left(\mathrm{SC}-\mathrm{CO}_{2}\right)$ extraction. Int Food Res J. 2011; 18:543-7.

3. Bimakr M, Rahman RA, Taip FS, Chuan LT, Ganjloo A, Salleh LMd, et al. Supercritical Carbon Dioxide (SC-CO2) Extraction of Catechin, Epicatechin, Rutin and Luteolin from Spearmint (Mentha spicata L.) Leaves. World Appl Sci J. 2008; 5:410-17.

4. Choudhury RP, Kumar A, Garg AN. Analysis of Indian mint (Mentha spicata) for essential, trace and toxic elements and its antioxidant behaviour. J Pharm Biomed Anal. 2006; 41:825-32.

5. Chowdhury JU, Nandi NC, Uddin M, Rahman M. Chemical Constituents of Essential Oils from Two Types of Spearmint (Mentha spicata L. and M. cardiac L.) Introduced in Bangladesh. Bangladesh J Sci Ind Res. 2007; 42:79-82.

6. Mathew Attokaran, Spearmint Natural Food and Colorants. [online] [cited 2016 April 28]; available from: www.onlinelibrarywiley.com

7. Guney M, Oral B, Karahanli N, Mungan T, Akdogan M. The effect of mentha spicata labiatae on uterine tissue in rats. Toxicol Ind Health. 2006; 22:343-8.

8. Akdogan M, Ozguner M, Aydin G, Gokalp O. Investigation of biochemical and histopathological effects of menthapiperita labiatae and mentha spicata labiatae on liver tissue in rats. Hum Exp Toxicol. 2004; 23:21-8.

9. Mugisha MK, Ndukui JG, Namutembi A, Waako P, Karlson AKB, Vudriko P. Acute and Sub-Acute Toxicity of Ethanolic Leaf Extracts of Rumexabyssinica Jacq. (Polygonaceae) and
Mentha spicata L. Pharmacol Pharm. 2014; 5:309-18.

10. Orav A, Kapp K, Raal A. Chemosystematic markers for the essential oils in leaves of Mentha species cultivated or growing naturally in Estonia. Proc Est Acad Sci.2013;62,3:175-86

11. Saleem M, Alam A, Sultana S. Atteenuation of benzoyl peroxide-mediated cutaneous oxidative stress and hypoproliferative response by the prophylactic treatment of mice with spearmint (Mentha spicata). Food Chem Toxicol. 2000; 38:939-48.

12. Shaikh S, Yaacob HB, Abdur Rahim ZH. Prospective role in treatment of major illnesses and potential benefits as a safe insecticide and natural food preservative of mint (mentha spp.): A Review. Asian J Biomed Pharm. 2014; 4:1-12.

13. Cakilcioglu U, Khatun S, Turkoglu I, Hyata S. Ethnopharmacological survey of medicinal plants in Maden (Elazig-Turkey). J Ethnopharmacol. 2011; 137:469-86.

14. Najaran ZT, Firoozi ET, Nasiri R, Jalali N, Hassaszadeh MK. Antiemetic activity of volatile oil from Mentha spicata and Mentha piperita in chemotherapy induced nausea and vomiting. Ecancer. 2013; 7:1-6.

15. Bulat R, Fachnie E, Chawhan U, Chen Y, Tougas G. Lack of effects of spearmint on lower oesophageal sphincter function and acid reflux in healthy volunteers. Aliment Pharmacol Ther. 1999; 13:805-12.

16. Akdogan M, Kilinc I, Oncu M, Karaoz E, Delibas N. Investigation of biochemical and histopathological effects of menthapiperita labiatae and Menthaspicata labiatae on kidney tissue in rats. Hum Exp Toxicol. 2003;22:213-9.

17. Flecknell PA. Laboratory animal anesthesia. $3^{\text {rd }}$ Ed. London: Academic Press; 2009.

18. Neal MJ. The hyperalgesic action of barbiturates in mice. Brt J Pharmacol. 1965; 24:170-7.

19. Dhungel S, Mukerjee B. Longitudinal study of the effect of chronic stresses on postnatal growth of the body and its constituents parts in male albino rat. J Anat Soc Ind. 2007; 56:18-24.

20. Akdogan M, Tamer MN, Cure E, Cure MC, Koroglu BK, Delibaş N. Effect of spearmint (Mentha spicata Labiatae) teas on androgen levels in women with hirsutism. Phytother Res. 2007; 21:444-7.

21. Dorman HJ, Bachmayer O, Kosar M, Hiltunen R. Antioxidant properties of aqueous extracts from selected lamiaceae species grown in Turkey. J Agric Food Chem. 2004; 52:762-70. 
22. Dresser GK, Wacher V, Wong S, Wong HT, Bailey DG. Evaluation of peppermint oil and ascorbyl palmitate as inhibitors of cytochrome P4503A4 activity in vitro and in vivo. Clin Pharmacol Ther. 2002; 72:247-55.

23. Yousof V and N, Soltany A. Effects of Hydroalcoholic Extract of Dill (Anethumgraveolens) on the serum levels of blood lipids (cholesterol, Triglycerides, LDL and HDL) in male NMRI mice. J Pharm Chem Biol Sci March-May 2015; 3(1):114-121

24. Monsefi M, Ghasemi A, Alaee S, Aliabadi E. Effects of Anethumgraveolens L. (dill) on Oocyte and Fertility of Adult Female Rats. J Reprod Infertil. 2015; 16:10-7.

25. Nozhat F, Alaee S, Behzadi K, Chegini NA. Evaluation of possible toxic effects of spearmint (Mentha spicata) on the reproductive system, fertility and number of offspring in adult male rats. Avicenna J Phytomed (AJP). 2013;4:420-9.

26. El-Fadel T, Buchbauer G. Compilation of toxicological data of major volatile essential oil components. Mag pharm. 2012; 13:38-9.

\section{The Authors:}

Dr. Asma Zulfiqar,

Assistant Professor,

Department of Anatomy,

Fatima Memorial College of Medicine and Dentistry, Lahore.
Prof. Muhammad Suhail,

Head Department of Anatomy,

Shaikh Zayed Medical Complex, Lahore.

Dr. Javaid Iqbal

Associate Professor,

Department of Anatomy,

Shaikh Zayed Medical Complex, Lahore.

Dr. Tayyaba Muzaffar,

Assistant Professor,

Department of Anatomy,

Shaikh Zayed Medical Complex, Lahore.

Dr. Sitwat Mudassir

Assistant Professor,

Department of Anatomy,

University College of Medicine \& Dentistry,

University of Lahore

\section{Corresponding Author:}

Dr. Asma Zulfiqar,

Assistant Professor,

Department of Anatomy,

Fatima Memorial College of Medicine and Dentistry,

Lahore.

E-mail: drasmazulfiqar@yahoo.com 